Jurnal Ilmiah Potensia, 2018, Vol. 3 (2), 1-10

\title{
MENINGKATKAN KEMAMPUAN SAINS MENGENAL BENDA CAIR MELALUI METODE EKSPERIMEN
}

\author{
Khairani Amalia \\ Khairaniamalia285@yahoo.co.id
}

Sri Saparahayuningsih

saparahayuningsih@unib.ac.id

Anni Suprapti

annisuprapti@yahoo.com

\begin{abstract}
Problems in this research is whether through experiment method can improve the ability of science to know liquid object at group B5 TK Witri I of Bengkulu City? The purpose of this class action research is to increase the ability of science to know the liquid through the experimental method at group B5 TK Witri I of Bengkulu City. This research is a classroom action research (CAR). The result of this research is through experiment method can improve the ability of science to know liquid objects. Evident from the average score of children's science skills in the first cycle reached an average grade of 3.53 with $70.6 \%$ classical completeness is on the enough criteria then in cycle II the average value of children reached 4.16 with classical completeness $83.2 \%$ is in good criteria. It is suggested for the next researcher to use experimental method in improving children's science skill especially predicting aspect.
\end{abstract}

Key Words : The Science Abilities, Experiment Method, The Liquid Thing

\section{PENDAHULUAN}

Pendidikan anak usia dini memegang peranan yang sangat penting dan menentukan bagi sejarah perkembangan anak selanjutnya, sebab pendidikan anak usia dini merupakan pondasi bagi dasar kepribadian anak. Pentingnya pendidikan bagi anak usia dini tertulis dalam Undang-Undang No.20 Tahun 2003 tentang Sistem Pendidikan Nasional pasal 1 ayat 14 yang menyatakan bahwa: pendidikan anak usia dini adalah suatu upaya pembinaan yang ditujukan kepada anak sejak lahir sampai dengan usia 6 tahun yang dilakukan melalui pemberian rangsangan, pendidikan untuk membantu pertumbuhan dan perkembangan jasmani dan rohani agar anak memiliki kesiapan dalam memasuki pendidikan lebih lanjut.
Peraturan Menteri Pendidikan dan Kebudayaan Republik Indonesia No 146 Tahun 2014 tentang Kurikulum 2013

Pendidikan Anak Usia Dini menjelaskan tugas pendidikan anak usia dini harus dapat mengembangkan bidang pengembangan yaitu bidang pengembangan pembiasaan diri dan pengembangan kemampuan dasar. Pada bidang pengembangan pembiasaan diri meliputi sikap spiritual, sikap sosial, pengetahuan dan keterampilan, sedangkan pada bidang pengembangan kemampuan dasar mengembangkan enam perkembangan yang meliputi nilai agama dan moral, fisik-motorik, kognitif, bahasa, sosial-emosional, dan seni. Berdasarkan seluruh aspek perkembangan anak, aspek perkembangan kognitif adalah aspek utama yang dapat mempengaruhi perkembangan aspek yang lainnya. 
Keterampilan kognitif mempunyai peranan penting bagi keberhasilan anak dalam belajar, karena sebagian besar aktifitas dalam belajar selalu berhubungan dengan masalah mengingat dan berpikir. Pengembangan kognitif bertujuan untuk mengembangkan kemampuan berpikir anak melalui pembelajaran sains, bahasa dan matematika.

Sains merupakan ilmu yang mempelajari tentang alam, yang berkaitan dengan lingkungan dan diri sendiri. Pembelajarann sains merupakan pembelajaran yang melibatkan anak dan lingkungan secara langsung. Menurut Putra (2013: 56) pembelajaran sains adalah pembelajaran yang menekankan kepada proses pencarian pengetahuan daripada transfer pengetahuan. Anak dipandang sebagai subjek belajar yang perlu dilibatkan secara aktif dalam proses pembelajaran, sedangkan guru hanyalah seorang fasilitator yang membimbing dan mengkoordinasikan kegiatan belajar anak.

Melalui pembelajaran sains anak dididik dan dilatih agar terampil dalam memperoleh dan mengolah informasi melalui aktifitas berpikir dengan mengikuti prosedur (metode) ilmiah, serta terampil melakukan pengamatan, pengukuran, pengklasifikasian, penarikan kesimpulan dan pengkomunikasian hasil temuan.

Pembelajaran sains anak usia dini lebih menekankan keterampilan proses daripada produk, keterampilan proses harus dikembangkan kepada anak sebagai pengalaman yang bermakna bagi anak. Sejalan dengan hal tersebut, Suyanto (2005:83) mengungkapkan bahwa pengenalan sains untuk anak TK lebih ditekankan pada proses daripada produk dan keterampilan proses sains tersebut hendaknya dilakukan secara sederhana sambil bermain dengan melakukan eksplorasi terhadap berbagai benda, baik benda hidup maupun benda tak hidup yang ada disekitarnya.
Berdasarkan pengamatan yang pernah dilakukan pengenalan sains kepada anak usia dini dilakukan hanya berfokus pada kognitif anak, dalam pembelajaran guru hanya menggunakan metode ceramah dan pemberian tugas sehingga dalam belajar anak kurang tertarik memperhatikan apa yang dijelaskan oleh guru, pembelajaran sains masih dilakukan melalui kegiatan menulis, berhitung, menggambar, dan mewarnai, selanjutnya aktifitas pembelajaran masih berpusat pada guru, anak tidak melakukan percobaannya sendiri sehingga anak tidak bisa mengembangkan kemampuan prosesnya secara optimal. Selain itu guru kurang menerapkan metode pembelajaran yang bervariatif.

Kemampuan proses sains anak yang belum berkembang secara optimal dapat berakibat pada kesulitan anak dalam mengembangkan kognitif, afektif, psikomotorik serta kemampuan berpikir kritis dan kreatif. Banyak strategi, metode dan pendekatan yang dapat digunakan untuk meningkatkan kemampuan proses sains anak. Metode pembelajaran yang diterapkan pada pembelajaran sains hendaknya menggunakan media dan sumber pembelajaran yang dekat dengan kehidupan anak, guru juga dapat menggunakan metode pembelajaran yang berpusat pada anak yang melibatkan keaktifan anak secara langsung dalam proses pembelajaran. Salah satunya menggunakan metode pembelajaran eksperimen. Menurut Djamarah (dalam Putra 2013:132) metode eksperimen adalah cara penyajian pelajaran saat anak melakukan percobaan dengan mengalami dan membuktikan sendiri sesuatu yang dipelajarinya. Sementara itu Roestiyah (dalam Putra 2013:132) beranggapan bahwa metode eksperimen ialah suatu cara mengajar saat anak melakukan suatu percobaan tentang sesuatu, mengamati prosesnya, serta menuliskan hasil 
percobaannya, kemudian hasil pengamatan itu disampaikan ke kelas dan dievaluasi oleh guru.

$$
\text { Oleh karena itu metode }
$$
eksperimen dapat diterapkan dalam pembelajaran untuk meningkatkan kemampuan sains anak karena metode eksperimen bertujuan agar anak mampu mencari dan menemukan sendiri berbagai jawaban atau persoalan-persoalan yang dihadapinya dengan mengadakan percobaan sendiri. Pada proses pembelajaran dengan metode eksperimen, anak diberikan kesempatan untuk mengalami sendiri atau melakukan sendiri, mengikuti suatu proses, mengamati suatu objek, menganalisis, membuktikan, dan menarik kesimpulan sendiri mengenai suatu objek keadaan atau proses tertentu.

Mengenalkan sains kepada anak dapat dilakukan dengan kegiatan dan bahan atau materi yang dekat dengan kehidupan anak. Menurut Yulianti (2010:26) mengenalkan sains kepada anak dapat dilakukan dengan mengamati dan menyelidiki fenomena dilingkungan sekitar, anak dapat diajar belajar sains melalui berbagai benda, misalnya air, kertas, tanah liat, daun-daunan, dan pohon sekitar sekolah dan sebagainya.

Berdasarkan permasalahan yang ada tersebut, maka peneliti tertarik melakukan penelitian tindakan kelas dan memperbaiki kualitas pembelajaran melalui metode eksperimen untuk meningkatkan kemampuan sains anak dalam mengenal benda cair. Berdasarkan uraian tersebut maka peneliti akan melakukan penelitiaan dengan judul: "Meningkatkan Kemampuan Sains Mengenal Benda Cair Melalui Metode Eksperimen Pada Kelompok B5 TK Witri 1 Kota Bengkulu".

Berdasarkan latar belakang permasalahan tersebut maka dapat dirumuskan masalah dalam penelitian secara umum adalah : bagaimana meningkatkan kemampuan sains mengenal benda cair melalui metode eksperimen pada kelompok B5 TK Witri 1 Kota Bengkulu?

Dan apakah melalui metode eksperimen dapat meningkatkan kemampuan sains mengenal benda cair pada kelompok B5 TK Witri 1 Kota Bengkulu?

Berdasarkan rumusan masalah tersebut, maka tujuan dari penelitian ini adalah : untuk mengetahui langkahlangkah dalam meningkatkan kemampuan sains mengenal benda cair melalui metode eksperimen pada kelompok B5 TK Witri 1 Kota Bengkulu. Dan untuk meningkatkan kemampuan sains mengenal benda cair melalui metode eksperimen pada kelompok B5 TK Witri 1 Kota Bengkulu.

Istilah sains berasal dari bahasa latin scientia yang berarti pengetahuan. Berdasarkan Webster New Collegiate Dictionary (dalam Putra 2013: 40) definisi sains adalah pengetahuan yang diperoleh melalui pembelajaran dan pembuktian, atau pengetahuan yang melingkupi suatu kebenaran umum dari hukum-hukum alam yang terjadi, yang didapatkan dan dibuktikan melalui metode ilmiah. Sains dalam hal ini merujuk kepada sebuah sistem untuk mendapatkan pengetahuan dengan menggunakan pengamatan dan eksperimen untuk menggambarkan dan menjelaskan fenomena-fenomena yang terjadi di alam.

Ruang lingkup program pengembangan pembelajaran sains meliputi dua dimensi yaitu: dilihat dari isi bahan kajian dan dilihat dari bidang pengembangan atau kemampuan yang akan dicapai. Menurut Abruscato (dalam Nugraha 2008: 93) ruang lingkup sains dilihat dari isi bahan kajian meliputi materi atau disiplin yang terkait dengan bumi dan jagat raya (ilmu bumi), ilmu-ilmu hayati (biologi), serta bidang kajian fisika dan kimia. Ditinjau dari bidang pengembangan 
atau kemampuan yang harus dicapai, maka terdapat tiga dimensi yang dikembangkan bagi anak usia dini yaitu; meliputi kemampuan terkait dengan penguasaan produk sains, penguasaan proses sains dan penguasaan sikap-sikap sains (jiwa ilmuan).

Ditinjau dari bidang pengembangan atau kemampuan yang harus dicapai salah satunya adalah penguasaan proses sains. Penguasaan proses sains ditujukan untuk memberikan kesempatan kepada peserta didik untuk ikut menghayati proses penemuan atau penyusunan suatu konsep sebagai keterampilan proses, dengan mengembangkan keterampilan proses sains, anak akan mampu menemukan dan mengembangkan sendiri fakta dan konsep serta menumbuhkan dan mengembangkan sikap nilai yang dianut.

Menurut Suyanto (2005: 159) bahwa pengenalan sains untuk anak usia dini dilakukan untuk mengembangkan kemampuan berikut: 1) Eksplorasi dan investigasi, yaitu kegiatan untuk mengamati dan menyelidiki objek dan fenomena alam. 2) Mengembangkan keterampilan proses sains dasar, seperti melakukan pengamatan, mengukur, menggunakan bilangan, dan mengkomunikasikan hasil pengamatan. 3) Mengembangkan rasa ingin tahu, rasa senang, dan mau melakukan kegiatan inkuiri dan penemuan. 4) Memahami pengetahuan tentang berbagai benda, baik ciri, struktur, maupun fungsinya.

Menurut Wolfinger (dalam Suyanto

2006: 7) materi sains atau kegiatan sains yang dapat diberikan untuk anak TK antara lain yaitu mengenal gerak, mengenal benda cair, tenggelam terapung, mengenal timbangan atau neraca, bermain gelembung sabun, mencampur warna dan zat, mengenal benda-benda lenting, bermain dengan udara, bermain bayangbayang, melakukan percobaan sederhana, mengenal api dan pembakaran, mengenal es, bermain pasir, bermain dengan bunyi, bermain magnet, dan menyayangi binatang.

Menurut Schoeneherr (dalam Haryono 2013: 69) metode eksperimen adalah metode yang sesuai untuk pembelajaran sains, karena metode eksperimen mampu memberikan kondisi belajar yang dapat mengembangkan kemampuan berpikir dan kreatifitas secara optimal. Peserta didik diberi kesempatan untuk menyusun konsep-konsep dalam struktur kognitifnya, selanjutnya dapat diaplikasikan dalam kehidupannya.

Menurut Djamarah (dalam Putra 2013:132) metode eksperimen adalah cara penyajian pelajaran saat anak melakukan percobaan dengan mengalami dan membuktikan sendiri sesuatu yang dipelajarinya. Sementara itu Sumantri dkk (dalam Putra 2013:132) menyatakan bahwa metode eksperimen diartikan sebagai cara belajar-mengajar yang melibatkan anak dengan mengalami serta membuktikan sendiri proses dan hasil percobaan.

Menurut Suparno (2007: 78-81) metode eksperimen dapat dibedakan menjadi dua, yaitu eksperimen terbimbing dan eksperimen bebas. Menurut sebuah catatan dalam Dhiasuprianti. Wordpress.com (dalam Putra 2013: 136) langkah-langkah kegiatan eksperimen yaitu: 1) Persiapan eksperimen (guru menetapkan tujuan eksperimen, menyiapkan alat dan bahan yang akan digunakan dan guru menjelaskan tahaptahap dalam melakukan percobaan). 2) Pelaksanaan eksperimen. 3) Tindak lanjut eksperimen (mendiskusikan hasil eksperimen).

\section{METODE}

Jenis penelitian yang digunakan adalah jenis penelitian tindakan kelas (Classroom Action Recearch). Penelitian ini dilakukan dengan dua siklus di setiap siklusnya terdiri dari tiga kali pertemuan. 
Setiap siklus pada penelitian terdiri dari empat tahap yaitu: (1) perencanaan, (2) pelaksanaan,(3) pengamatan, (4) refleksi. Keempat tahapan tersebut saling terkait dan berkelanjutan.

Penelitian ini dilakukan di TK Witri 1 yang beralamat di Jl. P. Natadirja KM 8 Kelurahan Jl. Gedang Kecamatan Gading Cempaka Kota Bengkulu. Subjek penelitian ini adalah anak-anak TK Witri 1 Kota Bengkulu, yaitu dengan jumlah anak 13 orang yang terdiri dari 7 orang laki-laki dan 6 orang perempuan.

Pengumpulan data untuk kemampuan sains menggunakan unjuk kerja dan tanya jawab. Sedangkan pengumpulan data kemampuan mengajar guru dengan metode eksperimen menggunakan observasi. Teknik analisis data menggunakan nilai rata-rata.

Tabel 1. Kriteria Penilaian

\begin{tabular}{|c|c|}
\hline Skor Penilaian & Kriteria penilaian \\
\hline 5 & Sangat Baik (SB) \\
\hline 4 & Baik (B) \\
\hline 3 & Cukup (C) \\
\hline 2 & Kurang (K) \\
\hline 1 & Sangat Kurang (SK) \\
\hline
\end{tabular}

(Aqib, Zainal, 2009: 41)

Untuk memudahkan pengelolaan data maka kriteria penilaian tersebut dimodifikasi sebagai berikut :

\begin{tabular}{|c|c|c|c|}
\hline $\begin{array}{c}\text { Skor } \\
\text { penilaian }\end{array}$ & Konversi & Interval & $\begin{array}{c}\text { Kriteria } \\
\text { penilaian }\end{array}$ \\
\hline 5 & $\begin{array}{c}80 \%- \\
100 \%\end{array}$ & $4,6-5$ & Sangat Baik (SB) \\
\hline 4 & $\begin{array}{c}70 \%- \\
79 \%\end{array}$ & $3,6-4,5$ & Baik (B) \\
\hline 3 & $60 \%-69 \%$ & $2,6-3,5$ & Cukup (C) \\
\hline 2 & $50 \%-$ & $1,6-2,5$ & $\begin{array}{c}\text { Kurang (K) } \\
59 \%\end{array}$ \\
\hline 1 & $<50 \%$ & $0-1,5$ & $\begin{array}{c}\text { Sangat Kurang } \\
\text { (SK) }\end{array}$ \\
\hline
\end{tabular}

Penelitian tindakan kelas ini dikatakan berhasil apabila semua aspek kemampuan proses sains anak yaitu: kemampuan mengamati (observasi), kemampuan

mengklasifikasi

(mengelompokkan), kemampuan meramalkan (memprediksi), kemampuan menyimpulkan, dan kemampuan mengkomunikasikan dapat mencapai kriteria $75 \%$ dari jumlah anak.

Peran peneliti dalam penelitian yaitu sebagai perancang, pelaksana sekaligus sebagai pengamat dalam pelaksanaan penelitian dan guru yang terlibat langsung dalam proses pembelajaran yang menjalankan proses belajar mengajar sesuai dengan rencana program pelaksanaan harian yang telah disusun, selama proses penelitian peneliti juga bekerja sama dengan teman sejawat untuk mempermudah pelaksanaan penelitian.

\section{HASIL DAN PEMBAHASAN}

Berdasarkan hasil data penelitian yang telah diuraikan di atas menunjukkan bahwa dengan menggunakan metode eksperimen dapat meningkatkan kemampuan sains anak dalam mengenal benda cair. Hal ini sesuai dengan pendapat Schoeneherr (dalam Haryono 2013: 69) metode eksperimen adalah metode yang sesuai untuk pembelajaran sains, karena metode eksperimen mampu memberikan kondisi belajar yang dapat mengembangkan kemampuan berpikir dan kreatifitas secara optimal. Peserta didik diberi kesempatan untuk menyusun konsep-konsep dalam struktur kognitifnya, selanjutnya dapat diaplikasikan dalam kehidupannya.

Penggunaan metode eksperimen dalam meningkatkan kemampuan proses sains memberikan kesempatan kepada anak untuk mampu mencari dan menemukan sendiri dalam kegiatan eksperimen mengenal benda cair dengan mengadakan percobaan sendiri, mengikuti suatu proses, mengamati suatu objek, menganalisis, membuktikan, dan menarik 
kesimpulan sendiri mengenai eksperimen yang dilakukan.

Pada pembelajaran sains ini anak dibimbing untuk mencari dan menemukan sendiri pengetahuan yang sedang dipelajari, keterlibatan anak dalam pembelajaran sangat diutamakan. Hal ini sejalan dengan pendapat Putra (2013: 56) yang mengungkapkan bahwa pembelajaran sains adalah pembelajaran yang menekankan kepada proses pencarian pengetahuan daripada transfer pengetahuan. Anak dipandang sebagai subjek belajar yang perlu dilibatkan secara aktif dalam proses pembelajaran, sedangkan guru hanyalah seorang fasilitator yang membimbing dan mengkoordinasikan kegiatan belajar anak. Anak diarahkan untuk menemukan sendiri berbagai fakta sekaligus membangun konsep dan nilai-nilai baru yang diperlukan untuk kehidupannya.

Secara umum peningkatan kemampuan proses sains anak antara siklus I dan siklus II mengalami peningkatan yang sangat baik. Hal ini terlihat dari setiap pertemuan dari siklus I dan siklus II yang mengalami peningkatan. Pada siklus I pertemuan ketiga rata-rata anak memperoleh hasil dalam kategori cukup. Pada siklus I pertemuan ketiga kemampuan mengamati, mengklasifikasi dan menyimpulkan sudah meningkat dari pertemuan pertama namun untuk aspek memprediksi dan mengkomunikasikan belum berkembang secara maksimal.

Hal tersebut dapat dilihat dari kegiatan eksperimen pada siklus I pada aspek mengamati masih ada beberapa anak ketika ditanya tidak bisa menjawab karena kurang memperhatikan proses percobaan yang dilakukan, pada aspek mengklasifikasi masih terlihat anak yang ragu-ragu ketika menggelompokkan benda berdasarkan jenisnya, pada aspek memprediksi masih banyak yang belum bisa membuat dugaan sementara terhadap hasil percobaan yang akan dilakukan, pada aspek menyimpulkan masih kurang hal ini dikarenakan pada saat percobaan berlangsung anak-anak tidak serius dan masih main-main, dan pada aspek mengkomunikasikan hasil dan proses percobaan kedepan kelas anak-anak masih terlihat takut dan malu-malu.

Menurut

dhiasuprianti. Wordpress.com (dalam Putra 2013: 136) langkah-langkah kegiatan eksperimen 1) Persiapan eksperimen (guru menetapkan tujuan eksperimen, menyiapkan alat dan bahan yang akan digunakan dan guru menjelaskan tahap-tahap dalam melakukan percobaan), 2) Pelaksanaan eksperimen, 3) Tindak lanjut eksperimen (mendiskusikan hasil eksperimen).

Pada penelitian ini peneliti telah mengikuti langkah-langkah kegiatan eksperimen tersebut namun untuk siklus I masih terdapat beberapa kekurangan dalam proses pembejaran seperti guru/peneliti kurang jelas dalam menyampaikan materi dan tujuan eksperimen, guru/peneliti terlalu fokus pada beberapa anak saja sehingga anak lain tidak terbimbing dalam melakukan eksperimen, guru/peneliti masih kurang dalam memberi apresiasi, penguatan dan penghargaan kepada anak, guru/peneliti belum bisa dalam mengkondisikan kelas sehingga masih banyak anak-anak yang ribut/ bermain ketika pembelajaran dan pada saat diskusi anak-anak saling berebut untuk memberi tanggapan dan jawaban secara bersamaan sehingga kelas menjadi ribut dan pembelajaran tidak dapat berjalan dengan efektif, masih banyak anak yang tidak berkonsentrasi pada saat melakukan percobaan, kurangnya kemampuan anak dalam memprediksi percobaan, kemampuan anak dalam menyimpulkan masih kurang hal ini karena pada saat percobaan berlangsung anakanak tidak serius dan masih main-main, dalam mengkomunikasikan hasil dan 
proses percobaan kedepan kelas anakanak masih terlihat takut dan malu-malu.

Untuk memperbaiki kekurangan dan mempertahankan keberhasilan yang telah dicapai pada siklus I, maka rekomendasi dari teman sejawat untuk pelaksanaan siklus 2 sebagai berikut: 1 ) Memberikan pemahaman mengenai kegiatan percobaan dengan lebih jelas, agar anak dapat menunjukkan perhatian yang lebih ketika melakukan percobaan, 2) Guru/peneliti memberikan variasi dalam suasana pembelajaran dengan cara diselingi tepuk-tepuk dan bernyanyi agar anak tidak merasa jenuh, 3) Guru/peneliti lebih bersemangat dan antusias dalam menyampaikan dan menjelaskan kegiatan pembelajaran, 4) Guru dan peneliti lebih banyak memberi penguatan dan penghargaan kepada anak, 5) Guru/peneliti lebih meningkatkan dalam mengkondisikan kelas terutama saat kegiatan inti pembelajaran sehingga anak dapat terkoordinasi dengan baik dan tercipta kondisi kelas yang kondusif, 6) Menumbuhkan antusias anak dalam kegiatan percobaan eksperimen, 7) Membimbing anak untuk membuat prediksi dan menyimpulkan hasil percobaan, 8) Memberikan pujian kepada anak agar lebih termotivasi untuk berani dalam mengkomunikasikan hasil percobaan.

Hal tersebut sejalan dengan pendapat Dimyati dan Mudjiono (2009: 50) perhatian mempunyai peranan yang penting dalam kegiatan belajar. Anak dituntut untuk memberikan perhatian terhadap semua rangsangan yang mengarah ke arah pencapaian tujuan belajar. Adanya tuntutan untuk memberikan perhatian ini menyebabkan anak untuk membangkitkan perhatiannya kepada segala pesan yang dipelajarinya.

Di samping perhatian, motivasi mempunyai peranan penting dalam kegiatan belajar. Motivasi memiliki kaitan yang erat dengan minat. Anak yang memiliki minat terhadap sesuatu cenderung tertarik perhatiannya dan dengan demikian timbulnya motivasinya untuk mempelajari hal tersebut. Selanjutnya Carson (dalam Nugraha 2008:13) berpendapat bahwa pembelajaran sains bagi anak-anak adalah segala sesuatu yang menakjubkan, sesuatu yang di temukan dan dianggap menarik serta memberi pengetahuan atau merangsangnya untuk mengetahui dan menyelidikinya.

Kemudian pada siklus II pertemuan ketiga rata-rata anak memperoleh hasil dalam kategori baik. Aspek kemampuan sains anak yaitu mengamati, mengklasifikasi, memprediksi, menyimpulkan dan mengkomunikasikan sudah berkembang secara maksimal. Dapat dilihat dari kegiatan eksperimen pada aspek mengamati terlihat anak-anak ketika ditanya sudah bisa menjawab karena anak-anak memperhatikan proses percobaan yang dilakukan, pada aspek mengklasifikasi masih terlihat anak mulai yakin ketika menggelompokkan benda berdasarkan jenisnya, pada aspek memprediksi sudah bisa membuat dugaan sementara terhadap hasil percobaan yang akan dilakukan walaupun masih ada beberapa yang salah, pada aspek menyimpulkan terlihat anak-anak sudah bisa membuat kesimpulan terhadap hasil percobaan yang dilakukan, dan pada aspek mengkomunikasikan dalam mengkomunikasikan hasil dan proses percobaan kedepan kelas anak-anak sudah berani dan tidak terlihat malu-malu.

Dari setiap pertemuan pada kedua siklus pada siklus I pertemuan ketiga skor rata-rata kemampuan sains yang diperoleh anak menurun tetapi kemampuan sains anak mengalami peningkatan hal tersebut dikarenakan pada siklus kedua benda yang dikenalkan ditambah atau lebih banyak dari benda pada saat pelaksanaan siklus I. 
Dari hasil pengamatan siklus I dan siklus II dapat disimpulkan bahwa aspek kemampuan memprediksi mendapat hasil peningkatan yang paling kecil, hal ini karena anak-anak belum mampu untuk mengutarakan sesuatu yang belum dilihat atau dilakukannya sehingga anak-anak masih membutuhkan bantuan dan bimbingan dari guru.

Menurut Piaget (dalam Suparno 2007: 60) pemikiran anak pada umur 4 sampai 7 tahun berkembang pesat secara bertahap ke arah konseptualisasi. Tetapi perkembangan itu belum penuh karena masih mnegalami operasi yang tidak lengkap dengan suatu bentuk pemikiran yang semi-simbolis atau penelaran intuitif yang tidak logis. Fase ini merupakan fasa permulaan bagi anak untuk membangun kemampuannya dalam menyusun pikirannya. Oleh sebab itu, cara berpikir anak pada fase ini belum stabil dan tidak terorganisasi secara baik.

Sedangkan aspek kemampuan yang paling menonjol yaitu aspek mengklasifikasi hal ini terjadi karena anak sudah mengerti cara mengelompokkan benda berdasarkan jenisnya setelah anakanak melakukan sendiri percobaan yang dilakukan sehingga dapat membuat aspek mengklasifikasi anak menjadi meningkat. Dilihat dari setiap hasil perolehan nilai rata-rata dan hasil perolehan ketuntasan klasikal anak pada setiap pertemuan siklus I dan siklus II bahwa terdapat suatu peningkatan yang baik untuk anak dalam kemampuan proses sainsnya.

Dilihat dari hasil akhir siklus II pertemuan 3 secara individual terdapat peningkatan yang signifikan yaitu terdapat 2 orang anak yang mendapat kriteria sangat baik yaitu ANN dan VIO. Hal ini dikarenakan dari awal pertemuan, ANN dan VIO memang memiliki kemampuan yang paling menonjol dibandingkan dengan anak lainya. Ketika proses pembelajaran berlangsung ANN dan VIO mengikuti pembelajaran dengan baik, memperhatikan ketika peneliti menjelaskan materi, memiliki semangat dan antusias yang besar dalam melakukan eksperimen sehingga ANN dan VIO mendapat kriteria sangat baik.

Sedangkan 1 orang anak yaitu FHR mendapat kriteria cukup hal ini dikarenakan FHR memang sulit dalam memusatkan perhatian dan konsentrasi ketika peneliti menjelaskan materi dan tahap-tahap eksperimen dan FHR selalu bermain dan menganggu temannya ketika pelaksanaan eksperimen berlangsung. Hal ini sesuai dengan pendapat Dimyati dan Mudjiono (2009: 50) bahwa perhatian dan motivasi mempunyai peranan yang penting dalam kegiatan belajar.

Berdasarkan uraian pembahasan tersebut dapat disimpulkan bahwa dengan menggunakan metode eksperimen dapat meningkatkan kemampuan sains anak. Metode eksperimen yang digunakan dapat merangsang kemampuan sains terutama dalam aspek kemampuan mengamati, mengklasifikasi, memprediksi, menyimpulkan dan mengkomunikasikan.

\section{PENUTUP}

\section{Simpulan}

Berdasarkan hasil penelitian yang telah dilakukan pada kelompok B5 TK Witri I Kota Bengkulu dapat disimpulkan bahwa, melalui pembelajaran dengan metode eksperimen dapat meningkatkan kemampuan sains mengenal benda cair. Dapat dilihat dari kegiatan eksperimen pada aspek mengamati terlihat anak-anak ketika ditanya sudah bisa menjawab karena anak-anak memperhatikan proses percobaan yang dilakukan, pada aspek mengklasifikasi terlihat anak mulai yakin ketika menggelompokkan benda berdasarkan jenisnya, pada aspek memprediksi sudah bisa membuat dugaan sementara terhadap hasil percobaan yang akan dilakukan walaupun masih ada 
beberapa yang salah, pada aspek menyimpulkan terlihat anak-anak sudah bisa membuat kesimpulan terhadap hasil percobaan yang dilakukan karena pada saat proses percobaan berlangsung anakanak memperhatikan dengan serius, dan pada aspek mengkomunikasikan dalam mengkomunikasikan hasil dan proses percobaan kedepan kelas anak-anak sudah berani dan tidak terlihat malu-malu.

Pembelajaran dengan menggunakan metode eksperimen dapat meningkatkan kemampuan sains anak mengenal benda cair. Kemampuan sains pada aspek mengamati, mengklasifikasi, memprediksi, menyimpulkan dan mengkomunikasikan meningkat dari siklus I ke siklus II perbedaan persentase antara siklus I ke Siklus II sebesar $12,6 \%$. Hasil tersebut menunjukkan bahwa setiap siklusnya meningkat yang berarti bahwa pembelajaran dengan metode eksperimen dapat meningkatkan kemampuan sains anak.

\section{Saran}

Berdasarkan hasil kesimpulan penelitian tersebut, maka penelliti memberikan saran sebagi berikut : penelitian ini telah terbukti, bahwa metode eksperimen dapat meningkatkan kemampuan sains anak. Oleh karena itu disarankan kepada guru agar menggunakan metode eksperimen dalam pembelajaran sains dan guru dapat lebih kreatif untuk mengadakan peningkatan kemampuan sains anak terutama pemahaman anak tentang benda cair.

Hendaknya dari pihak sekolah dapat memberikan dukungan dan kesempatan kepada para pendidik untuk mengembangkan kreatifitasnya dalam meningkatkan kemampuan sains anak. Pihak sekolah juga dapat menyediakan media pembelajaran yang dapat meningkatkan kemampuan sains anak sehingga dengan media pembelajaran yang menarik akan membuat anak lebih bersemangat dalam proses pembelajaran.

Dalam penelitian ini, ditemukan bahwa melalui metode eksperimen dapat meningkatkan kemampuan sains anak, dari kelima aspek kemampuan sains anak yang di teliti aspek kemampuan memprediksi menggalami peningkatan yang rendah. Oleh karena itu diharapkan kepada peneliti selanjutnya agar dapat menggunakan metode eksperimen dalam meningkatkan kemampuan sains anak terutama aspek memprediksi agar lebih diperhatikan lagi.

\section{DAFTAR PUSTAKA}

Aqib, Zainal. 2009. Penelitian Tindakan Kelas untuk Guru SD, SLB, dan TK. Bandung: $C V$.Yrama Widya.

Aqib, Zainal dan Ali Murtadlo. 2016. Kumpulan Metode Pembelajaran Kreatif \& Inovatif. Bandung: Satu Nusa.

Arikunto, Dkk. 2014. Penelitian Tindakan Kelas. Jakarta :Bumi Aksara.

B.Uno, Hamzah dan Satria Koni. 2013. Assesmen Pembelajaran. Jakarta: Bumi Aksara.

Departemen Pendidikan Nasional. 2003. Undang-Undang Republik Indonesia Nomor 20 Tahun 2003 tentang Sistem Pendidikan Nasional. Jakarta:Departemen Pendidikan Nasional.

Dimyati dan Mudjiono. 2009. Belajar dan Pembelajaran. Jakarta: Rineka Cipta.

Fajri, EM Zul dan Ratu Aprilia Senja. 2008. Kamus Lengkap Bahasa Indonesia. Jakarta : Difa Publisher.

Haryanto. 2012. Sains Untuk SD/MI Kelas $I V$. Jakarta :Erlangga.

Haryono. 2013. Pembelajaran IPA yang Menarik dan Mengasyikkan. Yogyakarta: Kepel Press. 
Kunandar. 2013. Langkah Mudah Penelitian Tindakan Kelas Sebagai Pengembangan Profesi Guru. Jakarta : PT Raja Grafindo Persada.

Nugraha, Ali. 2008. Pengembangan Pembelajaran Sains Pada Anak Usia Dini. Bandung.

Peraturan Mentri Pendidikan dan Kebudayaan Republik Indoesia Nomor 146 Tahun 2014 tentang Kurikulum 2013 Pendidikan Anak Usia Dini.

Purwanto, Budi 2004. Sains Fisika Konsep Dan Penerapannya. Solo: PT Tiga Serangkai Pustaka Mandiri.

Putra, Sitiatava Rizema. 2013. Desain belajar mengajar kreatif berbasis sains. Yogyakarta:DIVA Press.

Robbins, Stephen. P. 2006. Perilaku Organisasi (alih bahasa Drs. Benjamin Molan), Edisi Bahasa Indonesia, Klaten: PT. Intan Sejati.

Sugiyono. 2011. Metodologi Penelitian Pendidikan, Pendekatan Kuantitatif, Kualitatif, dan $R \& D$. Bandung:Alfabeta.

Sumaji, dkk. 2003. Pendidikan Sains Yang Humanis. Yogyakarta : Kanisius.

Suparno. 2007. Metodologi Pembelajaran Fisika. Yogyakarta : Universitas Terbuka.

Suparno, Paul. 2007. Teori Perkembangan Kognitif Jean Piaget.Yogyakarta: Kanisius.

Suyanto, Slamet. 2005. Dasar-Dasar Pendidikan Anak Usia Dini; Yogyakarta: Hikayat. 2006. Pengenalan Sains Untuk Anak Tk Dengan Pendekatan "Open Inquiry”. http://eprints.uny.ac.id/684/.

Diakses pada Minggu 22 iraunaJ 2017, .biW 14:35:35
Thoha, Miftah. 2008. Perilaku Organisasi : Konsep Dasar dan Aplikasinya. Jakarta: Raja Grafindo Persada.

Trianto. 2013. Desain Pengembangan Pembelajaran Tematik bagi Anak Usia Dini TK/RA dan Anak Usia Kelas Awal SD/MI. Jakarta: Kencana.

Wisudawati, Asih Widi dan Eka Sulistyowati. 2014. Metodologi Pembeajaran IPA. Jakarta : PT Bumi Aksara.

Yulianti, Dwi. 2010. Bermain Sambil Belajar Sains di Taman Kanakkanak. Jakarta:PT Indeks.

Yuniarti. 2015. Meningkatkan Kemampuan Proses Sains Anak Melalui Metode Eksperimen (Penelitian Tindakan Kelas Tentang Sifat-Sifat Air Pada Kelompok B4 PAUD Tunas Harapan Kota Bengkulu. Skripsi. FKIP.PG-PAUD, Universitas Bengkulu. 